\title{
Chemical characterization and oxidative stability of the oils from three morphotypes of Mauritia flexuosa L.f, from the Peruvian Amazon
}

\author{
By Pedro G. Vásquez-Ocmín, ${ }^{a}{ }^{\star}$ Luis Freitas Alvarado, ${ }^{a}$ Víctor Sotero Solís, ${ }^{a}$ Rosángela Paván \\ Torres $^{b}$ and Jorge Mancini-Filho ${ }^{b}$
}

${ }^{a}$ Laboratory of Natural Bioactive Substances, Peruvian Amazon Research Institute, Iquitos - Perú.

${ }^{b}$ Laboratory of Lipids, Department of Food and Experimental Nutrition, Faculty of Pharmaceutical

Sciences, University of São Paulo, São Paulo - Brazil.

( ${ }^{\star}$ Corresponding author: vasco2224@ gmail.com)

\section{RESUMEN}

Caracterización química y estabilidad oxidativa de los aceites de tres morfotipos de Mauritia flexuosa L.f., de la Amazonia Peruana.

Se estudiaron tres morfotipos de aguaje Mauritia flexuosa L. f., clasificados por el color del mesocarpio: "color", "shambo" y "amarillo", recogidos de localidades cercanas a la ciudad de lquitos- Perú. Del mismo modo a partir del mesocarpio se realizaron los análisis fisicoquímicos, la caracterización de los ácidos grasos por cromatografía gaseosa, la determinación de $\beta$-caroteno y $\alpha$ - tocoferol por cromatografía líquida de alta eficiencia (HPLC) fase reversa y normal y la determinación del tiempo de inducción de la oxidación en el equipo de Rancimat. A partir de la semilla se realizaron los análisis centesimales, de minerales y ácidos grasos. Los mesocarpios de aguaje son ricos en ácido oleico (amarillo: $75.63 \% \pm 0.31$ ), $\beta$-caroteno (amarillo: $342.42 \mathrm{ug} / \mathrm{g} \pm 0.71$ ) y $\alpha$ - tocoferol (color: $685.81 \mathrm{mg} / \mathrm{L} \pm 1.04$ ), y además el morfotipo "color" tiene un tiempo de inducción superior a los otros morfotipos con $6.91 \pm$ 0.01 , asimismo en la semilla de aguaje se encuentran cantidades considerables de $\omega 6$ (ácido linoleico) en "shambo" con $36.04 \pm 0.09 \%$. Los resultados obtenidos nos indican que estos aceites independientemente de la clasificación que se le asigne contienen importantes compuestos químicos que le brindan un altor valor nutricional.

PALABRAS CLAVE: Ácidos grasos - Aguaje - Estabilidad oxidativa - Mauritia flexuosa L.f. - Morfotipos.

\section{SUMMARY}

Chemical characterization and oxidative stability of the oils from three morphotypes of Mauritia flexuosa L.f. from the Peruvian Amazon.

Three morphotypes of aguaje Mauritia flexuosa were tested, classified by the color of their mesocarpium: "color", "shambo" and "amarillo", collected from different areas near the city of Iquitos,Peru. Also, physical-chemical analyses of the mesocarpium were performed, such as the characterization of fatty acids by gas chromatography, determination of $\beta$ - carotene y $\alpha$ - tocopherol by high efficiency liquid chromatography system in normal and reverse phase and the determination of oxidation induction time in the Rancimat apparatus. Proximate, mineral and fatty acid analyses were done on the seeds. The aguaje mesocarpium is rich in oleic oil (“amarillo": $75.63 \% \pm 0.31$ ), $\beta$-carotene ("amarillo": $342.42 \mathrm{ug} / \mathrm{g}$ \pm 0.71 ) and $\alpha$ - tocopherol ("color": $685.81 \mathrm{mg} / \mathrm{L} \pm 1.04$ ), plus the morphotype "color" has a superior oxidation induction time compared to other morphotypes with $6.91 \pm 0.01$. The aguaje seed contains significant amounts of $\omega 6$ (linoleic oil) in "shambo" with $36.04 \pm 0.09 \%$. The results indicate that these oils, regardless their classification, contain important chemical compounds that give them a special nutritive value.

KEY-WORDS: Aguaje - Fatty acids - Mauritia flexuosa L.f. - Morphotypes - Oxidative stability.

\section{INTRODUCTION}

Mauritia flexuosa L.f. (aguaje), is a palm tree, member of the Magnoliophyta division, the Liliopsida Class, Arecidae Sub-class, Arecales Order, Arecaceae Family (Cronquist, 1978). It grows in poorly drained soils, which suggests great resistance to flooding stress, explaining its tendency to grow and develop mainly in these kinds of soils (Ribeiro et al., 1998).

The geographic distribution of the aguaje is restricted mainly to South America, including the eastern side of the Andes of Colombia, Venezuela, Trinidad, the Guyanas, Ecuador, Peru, Bolivia and Brazil. (Henderson,1995). There are approximately six million hectares of aguaje forests in the Peruvian territory (Del Castillo et al., 2006), distributed mainly in the regions of San Martin, Huanuco, Madre de Dios, Cuzco, Loreto, Ucayali, Pasco (Kahn and Moussa, 1994), and the Amazons (Delgado et al., 2007).

The aguaje presents a great variability within the species. In the past, it was believed that there were two species of the Mauritia genera (M. Flexuosa y M. Vinifera Mart), with the first inhabiting the lower flooded areas, while the second was thought to inhabit the poorly drained upper areas along rivers. Now both of the Muaritia are considered the same species (Villachica, 1996). Nevertheless, the persistent variability is expressed mainly from the morphological point of view, taking into account the classifications of the species from indigenous persons. The Uitotos from Colombia, for example, have determined 21 "types" of aguaje (Urrego, 1987). There are other 
reports based mainly on the pigmentation of the aguaje fruit and, according to Villachica (1996), there are three "ecotypes" of aguaje: the ones with reddish mesocarpium called "shambo", the ones with fully yellow mesocarpium "ponguete", and another called "carnoso". Rojas (2000) adds, in the region of Loreto-Peru, phenotypically different trees are observed, with respect to fruits and as for plants, recognizes three "types" of aguaje according to the color of its mesocarpium: "amarillo", when the entire mesocarpium is yellow, "color" when the external part is red and the internal part is yellow, and "shambo" when the entire mesocarpium is red.

The aguaje, regardless of the morphological variability present in its fruits, represents an important source of chemical compounds such as the micro- and macronutrients sodium, potassium, calcium, iron, magnesium, manganese, copper and zinc, as well as other important phenolic compunds (Vásquez-Ocmín et al., 2009). The most important virtues are found in its oils, because of high rates of $\beta$ - carotene and the presence of important fatty acids. (Alburqueque et al. 2003; Alburqueque et al. 2005; Dias Ribeiro 2008; Rodríguez-Amaya 2001).

This work is aimed at chemically analyzing the oils of three Mauritia flexuosa L.f. morphotypes from the Peruvian Amazon.

\section{MATERIALS AND METHODS}

\subsection{Plant material}

Three morphotypes, classified by the color of their mesocarpium, were tested: "amarillo" presenting yellow colored mesocarpium, "shambo" presenting reddish colored mesocarpium and "color" presenting reddish colored external mesocarpium and yellow colored internal mesocarpium. These fruits were randomly collected in Aucayo (Coord. W: 0705593 y Coord. S: 09573034), Libertad (Coord. W: 0705846 y Coord. S: 09573256) and Centro Union (Coord. W: 0708456 y Coord. S: 09575376), villages located in the district of Fernando Lorez, province of Maynas, region of Loreto,Peru. The collected fruits were put in separate plastic recipients and then washed and disinfected with a continuous water flow. Water at $60^{\circ} \mathrm{C}$ was added to each recipient for an hour, with the purpose of forcing the ripening of the fruit, and later the exocarpum (the huso), the mesocarpium (pulp) and seed were separated by hand. The mesocarpium and seeds obtained were coded. The chemical analyses were made in the Laboratory of Natural Bioactive Substances of the Peruvian Amazon Research Institute.

\subsection{Analytical determination}

Proximate analyses were made to the obtained seeds using the methodology suggested by the Adolfo Lutz Institute (1985) and the mesocarpium and seeds oil were extracted using a soxhlet apparatus. Successive digestion was performed to the ashes obtained from the seeds, using chloridric acid $0,3 \mathrm{~N}$ for the determination of minerals, using the atomic absorption spectrophotometry equipment with an air-acetylene flame (Osborne and Voogt 1978; AOAC 2005).

For the oil extracted from the mesocarpium, physical-chemical analyses were made using the AOAC (2005) methodology. For the characterization of the mesocarpium and fatty acids of the seeds, they were derivatizated and sterificated using the methodology of Hartman and Lago (1973). The gas chromatography identification was analyzed on the equipment VARIAN 450-GC Supelcowax fused silicacolumn $60 \mathrm{~m}$ and 0,25 $\mathrm{mm}$ i.d, containing $0,25 \mu \mathrm{m}$ of poliethilenglicol, flame ionization detector (FID), using helium as carrier gas at $1.5 \mathrm{ml} / \mathrm{min}$ flow rate, column temperature programming with heating at $1^{\circ} \mathrm{C} / \mathrm{min}$, from $170^{\circ} \mathrm{C}$ to $225^{\circ} \mathrm{C}$, temperature detector $260^{\circ} \mathrm{C}$, sample in the injector split division rate $1 / 20$ (AOAC, 2005).

The determination of $\alpha$ - tocopherol was carried out by dissolving $1 \mathrm{~g}$ of oil in $10 \mathrm{ml}$ of $\mathrm{n}$-butane to achieve the saponification of the sample under a nitrogen flow in a hot water bath at $80^{\circ} \mathrm{C}$ with constant shaking. Later, water and hexane were added in a proportion of (2:4) and the sample was shaken in a vortex mixer, resulting in the formation of three distinct phases (Katsanidis and Addis, 1999). The intermediate phase was then isolated from the other phases and filtered through Puradisc $0,4 \mu \mathrm{m}$ filters, and later identified through HPLC, using a LiChroCART® 250-4 LiChrospher@ $\mathrm{NH}_{2}$ column, and Hexane/Ethyl acetate $(70: 30)$ as the mobile phase, with a $1.0 \mathrm{ml} / \mathrm{min}$ flow rate, diode arrangement detector (DAD), with a $290 \mathrm{~nm}$ wave length, injection volume $20 \mu \mathrm{L}$ (Doughty et al. 1996).

For the identification of $\beta$ - carotene, samples from the upper phase formed in the last paragraph were put in eppendorf tubes in order to dry them with a nitrogen flow, and after that the sample was suspended in $1 \mathrm{ml}$ of methanol HPLC, and was identified by HPLC reverse phase, using a LiChroCART® 250-4 LiChrospher@ RP-18 column, as mobile phase methanol grade HPLC $100 \%$, with $2 \mathrm{ml} / \mathrm{min}$ flow rate, diode arrangement detector (DAD), with a wave length of $250 \mathrm{~nm}$, injection volume of $20 \mu \mathrm{L}$ (Doughty et al. 1996).

The identification of the two compounds was made by comparison of retention time rates, related to the high purity standard and the quantification of area normalization, obtaining representative chromatograms for each analysis.

The determination of the forced oxidation induction time was made according to the methodology of the Metrohm manual (Rancimat 743), adapted for the Lipid Laboratory of the Faculty of Pharmaceutical Sciences of the University of São Paulo, for which two analysis groups were formed: the first group without any antioxidant, where $3 \mathrm{~g}$ of oil per morphotype and $3 \mathrm{~g}$ of soybean oil(control) were added separately into the reaction tubes; and the second group, with an antioxidant (Terhidroxibutilquinona - TBHQ, 2mg/ml), 
$3 \mathrm{~g}$ of oil for morphotype and $3 \mathrm{~g}$ of soybean oil(control) plus the antioxidant were added separately into the reaction tubes. The equipment was turned off when it was observed that the representative curves of the equipment were constant and the normal coloration of the oils changed. With the obtained times in the equipment, the antioxidant activity was determined using the following formula:

$$
\text { Antioxidant Activity }=\text { A / B }
$$

\section{Where:}

$A=$ Induction time of the oils subjected to the study.

$\mathrm{B}=$ Induction time of $\mathrm{s}$ soybean oil.

From the determination of antioxidant activity, the inhibition percentage to forced oxidation was determined by the following formula:

$\%$ Oxidation inhibition $=($ Antioxidant Activity $\mathrm{x}$ 100) -100

\subsection{Data analysis}

Triple analyses were done for all the samples and essays. The data analysis was done by means of an ANOVA using the statistical software JMP IN version 4.0.4 (Sall et al. 2001). When significance was observed in this test, the Tukey test was applied, also the letters shown in the tables differ if there are significant differences $p>0.05$.

\section{RESULTS AND DISCUSSION}

Table 1 shows the low amount of oil present in the seeds of each morphotype $(9.20 \pm 0.43 \%$ in morphotype "shambo"), when they are compared to the mesocarpium of each morphotype, as reported by Vásquez-Ocmin et al. (2009) they range from $25,20 \pm 0,10 \%$ (morphotype "shambo"). These values are inferior to those reported for sacha inchi Plukenetia volubilis by Bondoli and Della (2006) with $34.42 \%$. The average values of oils found is normal in the seeds, because of the majority (especially the smaller ones) are used as a main reserve source in the process of cellular respiration with the purpose of liberating enough energy to make it possible for the plant to establish and fixate in the soil (Salisbury and Ross 1992). Other important values found are total protein, of which the morphotype "amarillo" shows an outstanding amount, with $12.37 \pm 0.01 \%$, twice as much as the reported value for the mesocarpium of the morphotype "shambo" with 6,10 $\pm 0,10 \%$ (VásquezOcmín et. al. 2009), and inferior to that reported for sacha inchi with 34,21 $\pm 0,25 \%$ (Bondoli and Della 2006).

As shown in Table 2, the aguaje seeds contain important mineral elements, including a high potassium content $(1042.92 \pm 33.60 \mathrm{mg} / 100 \mathrm{~g})$ in the morphotype "shambo," almost twice as much as what was reported for the mesocapium of the morphotype "shambo" with $660.81 \pm 3.45 \mathrm{mg} / 100 \mathrm{~g}$ (Vásquez-Ocmín, 2009) and much more than in the grain of corn Zea mays $(170.11 \mathrm{mg} / 100 \mathrm{~g})$, the fruit of the nut Juglans regia L. $(337.92 \mathrm{mg} / 100 \mathrm{~g})$ and the seed of the peanut hypogaea L. $(603.59 \mathrm{mg} / 100 \mathrm{~g})$, as reported by Musa (2006).

Another important element in the mineral structure of the seeds is sodium, present in higher concentrations in the morphotype "amarillo" with $231.48 \pm 39.14 \mathrm{mg} / 100 \mathrm{~g}$, ten times as much as the value reported for the mesocarpium of the morphotype "shambo", with $20.76 \pm 0.19 \mathrm{mg} / 100 \mathrm{~g}$ (VásquezOcmín et al, 2009) and superior to that reported for corn $(53.58 \mathrm{mg} / 100 \mathrm{~g})$, nut $(65.04 \mathrm{mg} / 100 \mathrm{~g})$ and peanut $(78.74 \mathrm{mg} / 100 \mathrm{~g})$ by Musa (2006). According to the reports of Vásquez-Ocmín et al. (2009), superior contents of calcium and magnesium are observed for the mesocarpium of the aguaje (132.49 $\pm 1.31 \mathrm{mg} / 100 \mathrm{~g}$ y $98.61 \pm 0.06 \mathrm{mg} / 100 \mathrm{~g}$ for "shambo") in comparison to the values obtained from the seeds $(44.30 \pm 0.58 \mathrm{mg} / 100 \mathrm{~g}$ of calcium for "amarillo" and $67.65 \pm 5.99 \mathrm{mg} / 100 \mathrm{~g}$ of magnesium for "shambo").

According to Table 3 , the extracted oils from the mesocarpium show to have an optimum quality for consumption according to the results of the physical-chemical analyses which demonstrate the high peroxide index content and fusion point for the three morphotypes without showing any significant difference, matching with the results obtained by Trevejo (2003).Another important parameter is the acidity index, where the morphotype "shambo", proves to be different among the three.

Table 1

Proximate analyses of the seeds from three morphotypes of Mauritia flexuosa L.f.*

\begin{tabular}{lccc}
\hline \multicolumn{1}{c}{ Analysis (\%) } & $\begin{array}{c}\text { Amarillo } \\
\text { Mean } \pm \text { SD }\end{array}$ & $\begin{array}{c}\text { Color } \\
\text { Mean } \pm \text { SD }\end{array}$ & $\begin{array}{c}\text { Shambo } \\
\text { Mean } \pm \text { SD }\end{array}$ \\
\hline Humidity & $50,55^{\mathrm{a}} \pm 2,08$ & $48,07^{\mathrm{a}} \pm 0,94$ & $55,39^{\mathrm{b}} \pm 1,35$ \\
Ashes & $1,20^{\mathrm{a}} \pm 0,06$ & $1,31^{\mathrm{b}} \pm 0,05$ & $1,32^{\mathrm{b}} \pm 0,01$ \\
Oils & $7,37^{\mathrm{a}} \pm 1,03$ & $7,01^{\mathrm{a}} \pm 1,45$ & $9,20^{\mathrm{a}} \pm 0,43$ \\
Proteins & $12,37^{\mathrm{a}} \pm 0,01$ & $8,56^{\mathrm{b}} \pm 0,26$ & $9,90^{\mathrm{b}} \pm 0,51$ \\
Carbohydrates & $30,15^{\mathrm{a}} \pm 2,53$ & $35,03^{\mathrm{a}} \pm 1,96$ & $24,44^{\mathrm{c}} \pm 1,68$ \\
\hline
\end{tabular}

${ }^{\star}$ The data shown in the table represent the mean \pm Standard deviation (SD), and the letters differ when they are statistically different $\mathrm{p}<0.05$. 
Table 2

Mineral concentrations in seeds of three morphotypes of Mauritia flexuosa L.f.*

\begin{tabular}{lccc}
\hline Minerals & $\begin{array}{c}\text { Amarillo } \\
\text { Mg/100g }\end{array}$ & $\begin{array}{c}\text { Color } \\
\text { Mean } \pm \text { SD }\end{array}$ & $\begin{array}{c}\text { Shambo } \\
\text { Mean } \pm \text { SD }\end{array}$ \\
\hline Zinc & $1,28^{\mathrm{a}} \pm 0,07$ & $0,73^{\mathrm{b}} \pm 0,03$ & $1,25^{\mathrm{a}} \pm 0,01$ \\
Calcium & $44,30^{\mathrm{a}} \pm 0,58$ & $27,19^{\mathrm{b}} \pm 0,84$ & $34,81^{\mathrm{b}} \pm 5,45$ \\
Copper & $0,58^{\mathrm{a}} \pm 0,04$ & $0,37^{\mathrm{b}} \pm 0,02$ & $0,87^{\mathrm{c}} \pm 0,04$ \\
Sodium & $231,48^{\mathrm{a}} \pm 39,14$ & $80,25^{\mathrm{b}} \pm 2,08$ & $91,57^{\mathrm{b}} \pm 5,66$ \\
Magnesium & $60,53^{\mathrm{ac}} \pm 4,80$ & $52,37^{\mathrm{bc}} \pm 5,46$ & $67,65^{\mathrm{a}} \pm 5,99$ \\
Manganeso & $7,32^{\mathrm{a}} \pm 0,09$ & $5,82^{\mathrm{b}} \pm 0,02$ & $13,04^{\mathrm{c}} \pm 0,60$ \\
Potasium & $910,95^{\mathrm{a}} \pm 30,24$ & $809,88^{\mathrm{b}} \pm 22,87$ & $1042,92^{\mathrm{c}} \pm 33,60$ \\
Iron & $4,16^{\mathrm{a}} \pm 0,40$ & $1,51^{\mathrm{b}} \pm 0,22$ & $6,32^{\mathrm{c}} \pm 0,60$ \\
\hline
\end{tabular}

${ }^{*}$ The data shown in the table represent the mean \pm Standard deviation (SD), and the letters differ when they are statistically different $p<0,05$.

Table 3

Physical-chemical analyses of the oils extracted from the mesocarpium of three morphotypes of Mauritia flexuosa L.f.*

\begin{tabular}{lccc}
\hline \multicolumn{1}{c}{ Analysis } & $\begin{array}{c}\text { Amarillo } \\
\text { Mean } \pm \text { SD }\end{array}$ & $\begin{array}{c}\text { Color } \\
\text { Mean } \pm \text { SD }\end{array}$ & $\begin{array}{c}\text { Shambo } \\
\text { Mean } \pm \text { SD }\end{array}$ \\
\hline lodine index & $70,99^{\mathrm{a}} \pm 0,28$ & $70,38^{\mathrm{a}} \pm 0,11$ & $70,17^{\mathrm{b}} \pm 0,31$ \\
Saponification index & $191,34^{\mathrm{a}} \pm 0,28$ & $186,25^{\mathrm{b}} \pm 0,22$ & $194,89^{\mathrm{c}} \pm 0,41$ \\
Fusion point $\left({ }^{\circ} \mathrm{C}\right)$ & $11,0^{\mathrm{a}} \pm 1,0$ & $12,0^{\mathrm{a}} \pm 1,0$ & $10,3^{\mathrm{a}} \pm 0,57$ \\
Peroxide index (meq.de ox./Kg) & $11,12^{\mathrm{a}} \pm 5,36$ & $10,0^{\mathrm{a}} \pm 1,0$ & $12,46^{\mathrm{a}} \pm 0,49$ \\
Acidity index & $2,69^{\mathrm{a}} \pm 0,19$ & $2,13^{\mathrm{a}} \pm 0,40$ & $3,54^{\mathrm{b}} \pm 0,32$ \\
\hline
\end{tabular}

${ }^{\star}$ The data shown in the table represent the mean \pm Standard deviation (SD), and the letters differ when they are statistically different $\mathrm{p}<0,05$.

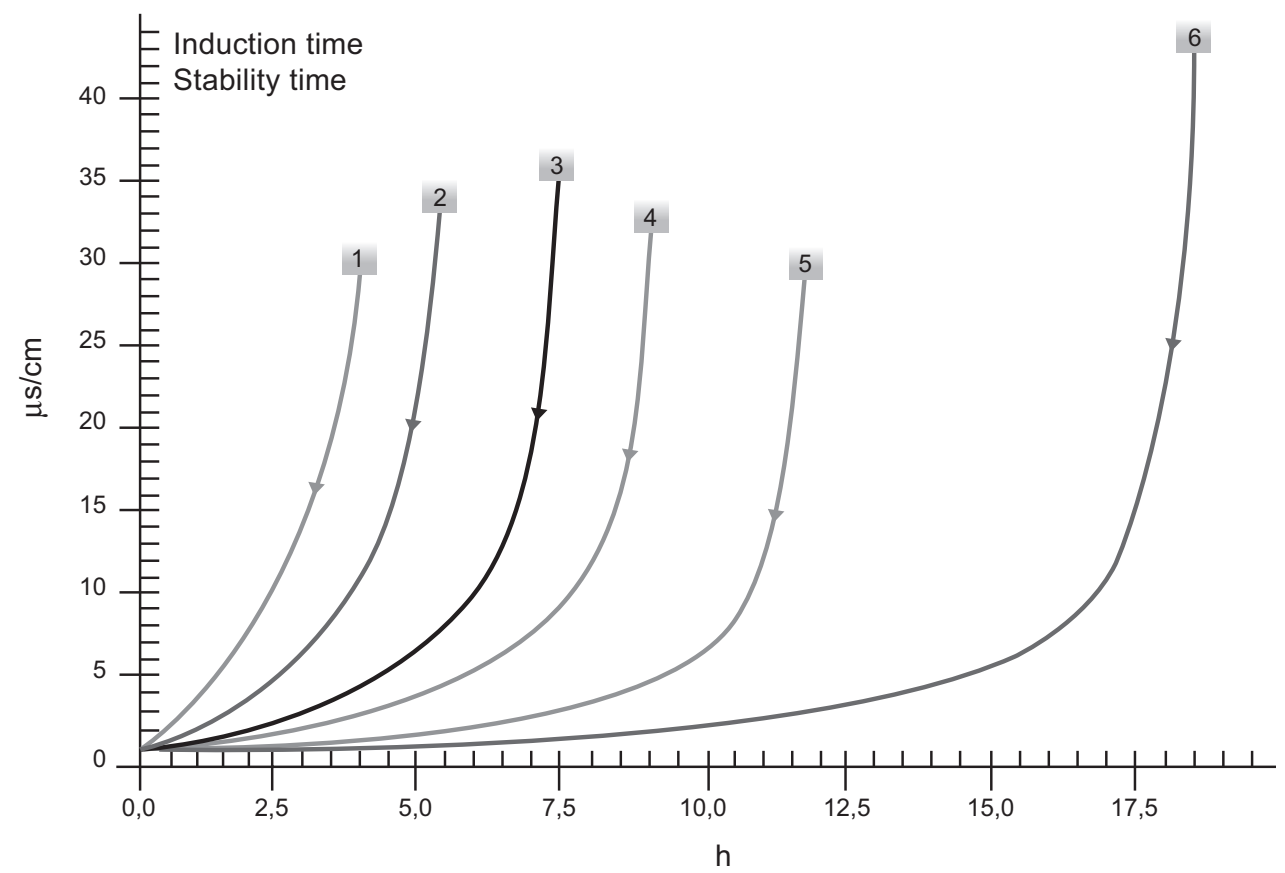

Figure 1.

Curves fof the aguaje oils expressed in time of induction.1= induccion time of "aguaje amarillo"; $2=$ induction time of "aguaje shambo"; $3=$ induction time of "aguaje color"; $4=$ induction time of "aguaje amarillo + TBHQ"; $5=$ induction time of "aguaje shambo + TBHQ";

$6=$ induction time of "aguaje color + TBHQ". 


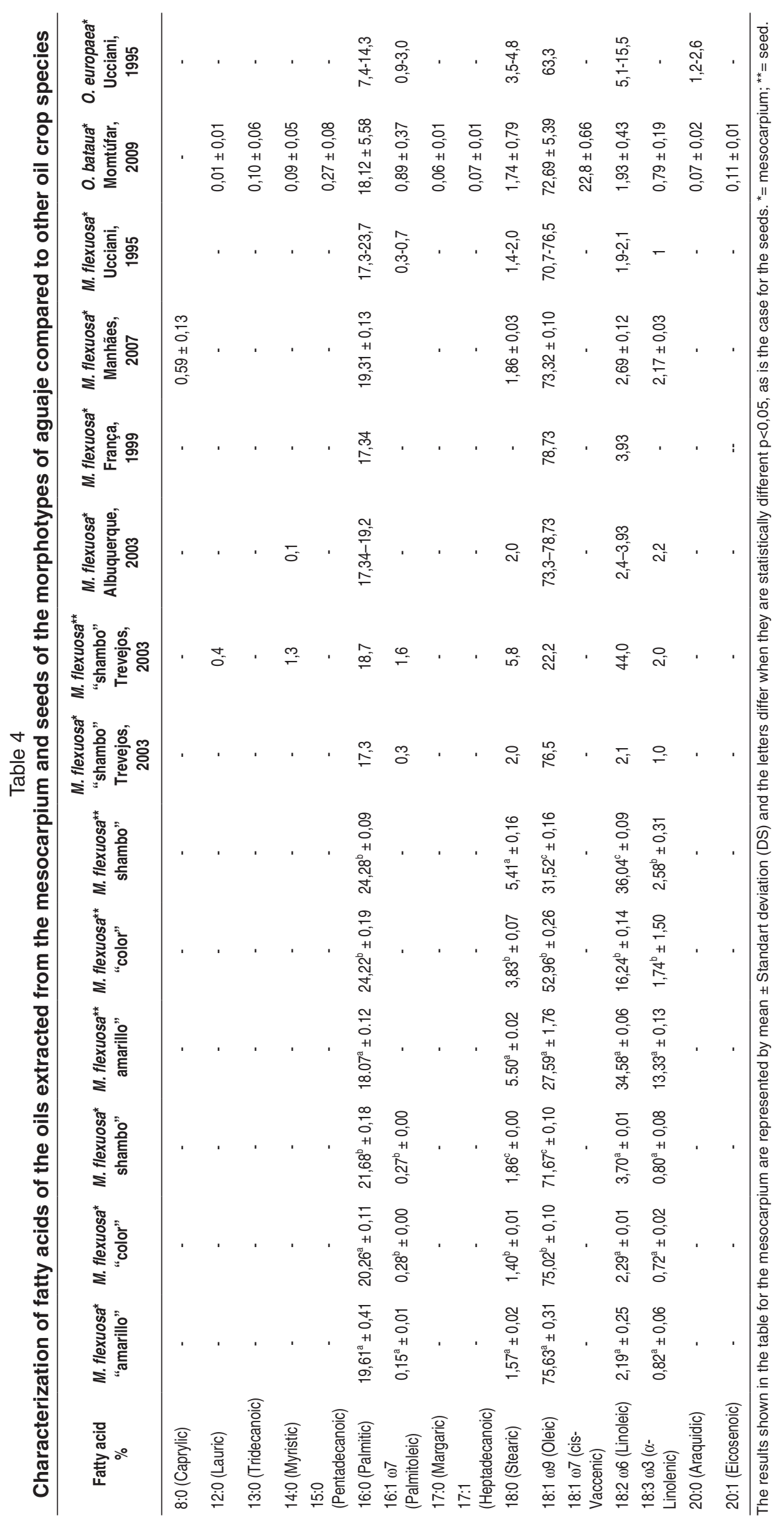


Table 4 illustrates that the fatty acid compositions of the different mesocarpiums do not vary, but there are some differences in the individual concentration of them, mainly the high oleic acid concentrations. The morphotype "amarillo" showed greater differences with $75,63 \pm 0,31 \%$ of oleic acid, similar to the reported figure by Trevejo (2003) with 76,5\%; Alburquerque (2003) with 73,3-78,73\%; Ferreira (1999) with 78,73\%; Manhães (2007) with 73,32 $\pm 0,10 \%$ and Ucciani (1995) with 70,7-76,5\%, and topping the reports for other species are ungurahui Oenocarpus bataua with 72,69 $\pm 5,39 \%$ (Momtúfar, 2009) and olive oil Olea europaea with 63,3\% (Ucciani, 1995).

The composition of fatty acids in the seeds is different to the composition of fatty acids in the mesocarpiums. The seeds demonstrate a high content of $\omega 6$ (linoleic acid), an important fatty acid and functional nutrient which, along with other antioxidant compounds, is capable of diminishing the disturbances occasioned by oxidative stress (Calder, 2003). Linoleic acid is found mainly in the morphotype "shambo" with $36.04 \pm 0.09 \%$, with a concentration higher than that found in Plukenetia volúbilis sacha inchi with $33.67 \%$ (Bondoli and Della 2006), oil palm Elaeis guineensis with 10.60 $\pm 0.46 \%$ (García et al. 2008) and olive oil Olea europaea with 7-9.8\% (Gunstone and Padley 1997), but inferior to the concentration reported by Trevejo (2003) for the seed of the aguaje "shambo" with $44.00 \%$. The morphotype "color" presents low $\omega 6$ concentration in comparison to the other two morphotypes, however this is the one that presents higher oleic acid concentrations with $52.96 \pm 0.26 \%$, succeeding the reported figure by Trevejo (2003) for aguaje "shambo" with $22,2 \%$.

According to Table 5, high $\beta$ - carotene concentration is observed in the morphotype "amarillo" with $324,42 \mathrm{ug} / \mathrm{g}$, similar to the one mentioned by De Rosso and Mercante (2007), with $514 \mu \mathrm{g} / \mathrm{g}$ of total carotene, of which it was identified that $372.32 \mu \mathrm{g} / \mathrm{g}$ corresponded to $\beta$ - carotene; also Rodríguez-Amaya (2001) reports $360 \mu \mathrm{g} / \mathrm{g}$, a content similar to the reported concentration in palm oil Elaeis guineensis with $363 \mu \mathrm{g} / \mathrm{g}$ (Trujillo-Quijano et al., 1990). A high concentration of $\alpha$ - tocopherol can be observed in the morphotype "color" with concentrations of $683.35 \mathrm{mg} / \mathrm{L}$, these being superior to its concentrations in corn oil Zea mays (600mg/L) and in olive oil Olea europaea (354mg/L), as reported by Sayazo et al (2007).

In Table 6 , the induction times of aguaje oils are shown, where the morphotype "color", has the highest time with 6.91 hours, being superior even to the obtained time for colza oil Brassica napus and olive oil Olea europea, reported by Boletín de aplicación Methrom (2008). Also in Table 7, forced oxidation inhibition percentage is demonstrated, where the morphotype "color", has the highest percentage at $87.96 \%$, which could be the result of

Table 5

Determination of $\beta$ - carotene, $\alpha$ - tocopherol by HPLC in oils extracted from the mesocarpium of three morphotypes of Mauritia flexuosa L.f.*

\begin{tabular}{lccc}
\hline Vitamines & $\begin{array}{c}\text { Amarillo } \\
\text { Mean } \pm \text { SD }\end{array}$ & $\begin{array}{c}\text { Color } \\
\text { Mean } \pm \text { SD }\end{array}$ & $\begin{array}{c}\text { Shambo } \\
\text { Mean } \pm \text { SD }\end{array}$ \\
\hline$\beta$ - caroteno $(\mathrm{ug} / \mathrm{g})$ & $324,42^{\mathrm{a}} \pm 0,71$ & $264,60^{\mathrm{b}} \pm 0,44$ & $283,57^{\mathrm{c}} \pm 0,48$ \\
$\alpha$ - tocoferol $(\mathrm{mg} / \mathrm{L})$ & $683,35^{\mathrm{a}} \pm 0,46$ & $685,8^{\mathrm{b}} \pm 1,04$ & $677,58^{\mathrm{c}} \pm 0,63$ \\
\hline
\end{tabular}

*The data shown in the table represent the mean \pm Standard deviation (SD), and the letters differ when they are statistically different $p<0,05$.

Table 6

Induction time of the oils of Mauritia flexuosa L.f.., and oil of Glycine max soybean (positive control)*

\begin{tabular}{lcccc}
\hline $\begin{array}{l}\text { Induction time } \\
\text { (hours) }\end{array}$ & $\begin{array}{c}\text { Amarillo } \\
\text { Mean } \pm \text { SD }\end{array}$ & $\begin{array}{c}\text { Color } \\
\text { Mean } \pm \text { SD }\end{array}$ & $\begin{array}{c}\text { Shambo } \\
\text { Mean } \pm \text { SD }\end{array}$ & $\begin{array}{c}\text { Soja } \\
\text { Mean } \pm \text { SD }\end{array}$ \\
\hline Without Antioxidant & $3,55^{\mathrm{a}} \pm 0,01$ & $6,91^{\mathrm{b}} \pm 0,01$ & $4,74^{\mathrm{c}} \pm 0,03$ & $3,68^{\mathrm{d}} \pm 0,03$ \\
UIT Antioxidant & $10,85^{\mathrm{a}} \pm 0,02$ & $17,96^{\mathrm{b}} \pm 0,01$ & $7,61^{\mathrm{c}} \pm 0,03$ & $6,68^{\mathrm{d}} \pm 0,03$ \\
\hline
\end{tabular}

${ }^{*}$ The data shown in the table represent the mean \pm Standard deviation (SD), and the letters differ when they are statistically different $p<0,05$.

Table 7

Forced oxidation inhibition percentage of the oils of three morphotypes of Mauritia flexuosa L.f.*

\begin{tabular}{lccc}
\hline $\begin{array}{l}\text { \% Forced oxidation } \\
\text { inhibition }\end{array}$ & $\begin{array}{c}\text { Amarillo } \\
\text { Mean } \pm \text { SD }\end{array}$ & $\begin{array}{c}\text { Color } \\
\text { Mean } \pm \text { SD }\end{array}$ & $\begin{array}{c}\text { Shambo } \\
\text { Mean } \pm \text { SD }\end{array}$ \\
\hline Without Antioxidant & $-3,44^{\mathrm{a}} \pm 0,38$ & $87,96^{\mathrm{b}} \pm 1,45$ & $28,80^{\mathrm{c}} \pm 0,23$ \\
With Antioxidant & $62,47^{\mathrm{a}} \pm 0,59$ & $168,86^{\mathrm{b}} \pm 1,05$ & $14,02^{\mathrm{c}} \pm 0,78$ \\
\hline
\end{tabular}

${ }^{*}$ The data shown in the table represent the mean \pm Standard deviation (SD), and the letters differ when they are statistically different $p<0,05$. 
a high content of $\alpha$ - tocoferol present in the oil. It can also be observed that the oils of the morphotypes with the right antioxidant mixture increase the induction time by three times (Figure 1).

\section{CONCLUSIONS}

The main virtue of the mesocarpium of aguaje Mauritia flexuosa L.f, independent of the morphotype, is expressed in its high $\beta$ - carotene, $\alpha$ - tocopherol, oleic acid contents and its oxidation resistance, which make it a high quality oil, superior to olive oil Olea europaea and palm oil Elaeis guineensis, which can be easily used by the nutraceutic product manufacturers. An important alternative to the use of aguaje seeds which are thrown in the streets of lquitos and other cities where it is consumed, is the extraction and use of its oils which contain a considerable concentration of $\omega 6$ (linoleic acid), important for diminishing the effects caused by oxidative stress.

\section{ACKNOWLEDGMENTS}

To the sub-project: Mejoramiento genético, caracterización molecular, y tecnologías de alto valor agregado del aguaje (Mauritia flexuosa L.f.) en la Amazonia Peruana", financed by Innovation and Competitiveness for the Peruvian Agriculture (INCAGRO) and the Peruvian Amazon Research Institute (IIAP), through the agreement IIAP INCAGRO. To the members of the Laboratory of Natural Bioactive Substances - IIAP, thank you for your support in the analyses. To the Ing. Juan Alejandro Vásquez Briones, for helping with the translation of this article to the English language.

\section{REFERENCES}

Adolfo Lutz. (1985). Normas analíticas do Instituto Adolfo Lutz. Métodos químicos e físicos para analise de alimentos. 2 ed. São Paulo. 1. 583.

Albuquerque MLS, Guedes I, Alcantara Jr, Moreira SGC. (2003). Infrared absorption spectra of Buriti (Mauritia flexuosa L.) oil. Vibrational Spectroscopy 33, 127131.

Albuquerque MLS, Guedes I, Alcantara Jr, Moreira SGC, Barbosa Neto NM, Correa DS, Zilio C. (2005). Characterization of Buriti (Mauritia flexuosa L.) Oil by Absorption and Emission Spectroscopies, Journal of the Braziliam Chemical Society 16, 1113-1117.

Application Bulletin. (2008). Analysis of edible oils and fats. Methrom. No. $141 / 3$ e. Bondioli P, Della BL. (2006). Alpha linolenic acid rich oils.Composition of Plukenetia volubilis (Sacha Inchi) oil from Perù. La Rivista Italiana delle Sostanze Grasse 78, 120-123.

Calder PC. (2003). Long-chain n-3 fatty acids and inflammation: potential application in surgical and trauma patients. Brazilian Journal of Medical and Biological Research 36, 433-446.

Cronquist A. (1978). The evolution and classification of flowering plants. The New York Botanical Garden, 2da Edic. New York, USA.
Del Castillo D, Otárola E, Freitas L. (2006). Aguaje, la maravillosa palmera de la Amazonía. Instituto de Investigaciones de la Amazonía Peruana. Ediciones Wust. 51.

Delgado C, Couturier G, Mejía K. (2007). Mauritia flexuosa (Arecaceae: Calamoideae), an Amazonian palm with cultivation purposes in Peru. Fruits 62, 157-159.

De Rosso VV, Mercadante AZ. (2007). Identification and Quantification of Carotenoids, By HPLC-PDA-MS/ MS, from Amazonian Fruits. Journal of Agricultural and Food Chemistry 55, 5062 -5072.

Dias Ribeiro B. (2008). Aplicação de Tecnologia Enzimática na Obtenção de $\beta$-Caroteno a partir de Óleo de Buriti (Mauritia vinifera). Dissertação de Mestrado. Universidade Federal do Río de Janerio.

Doughty E, Herwehe K, Yearick V. (1996). Soluble Vitamin Analyses by HPLC. The Supelco Reporter 15, 4-5.

Ferreira DFL, Reber G, Meireles AMA, Machado NT, Brunner G. (1999). Supercritical extraction of carotenoids and lipids from buriti (Mauritia flexuosa), a fruit from the Amazon region. Journal of Supercritical Fluids 14, 247-256.

García DSD, Sandoval DAJ, Saldaña RR, Cárdenas DRG, Soplín RJA, Sotero SV, Pavan TR, Mancini FJ. (2008). Fraccionamiento e interesterificacion del aceite de palma (Elaeis guineensis) cultivado en la amazonia peruana. Grasas y Aceites 59, 104-109.

Gunstone FD, Padley FB. (1997). Lipid Technologies and Applications, Marcel Dekker, Inc., Nova York.

Hartman L, Lago RCA. (1973). Rapid Preparation Of Fatty Acid Methyl Esters From Lipds. Lab. Pract. 22, 475-477.

Henderson A. (1995). The Palmae of the Amazon. Oxford University Press, New York. 326.

Kahn F, Moussa F. (1994). Las palmeras del Perú. Inst. Fr. Estad. Andin. IFEA. Lima, Perú.

Katsanidis E, Addis P. (1999). Novel HPLC analysis of tocopherols, tocotrienols, and cholesterol in tissue. Free Radical Biology \& Medicine 27, 1137-1140.

Manhães LRT. (2007). Caracterização da polpa de buriti (Mauritia flexuosa, Mart.): um potente alimento funcional. Seropédica: UFRRJ, 2007. 78p. Dissertação (Mestrado em Ciência e Tecnologia de Alimentos). Instituto de Tecnologia, Curso de Pós-Graduação em Ciência e Tecnologia de Alimentos, Universidade Federal Rural do Rio de Janeiro, Seropédica, RJ.

Manual Metrohm del aparato de Rancimat 743, adaptado el Laboratorio de lípidos del Departamento de Alimentos y Nutrición experimental de la Facultad de Ciencias Farmacéuticas de la Universidad de São Paulo.

Montúfar R, Laffargue A, Pintaud JC, Hamon S, Avallone S, Dussert S. (2010). Oenocarpus bataua Mart. (Arecaceae): Rediscovering a Source of High Oleic Vegetable Oil from Amazonia. J. Am. Oil Chem. Soc. 87, 167-172.

Musa Özcan M. (2006). Determination of the mineral compositions of some selected oil-bearing seeds and kernels using Inductively Coupled Plasma Atomic Emission Spectrometry (ICP-AES). Grasas y Aceites 57, 211-218.

Official Methods of Analysis of AOAC international. (2005). 18 Edition. USA.

Osborne DR, Voogt P. (1978). Análisis de los nutrientes de los alimentos. Editorial Acribia, S.A. Zaragoza (España).

Ribeiro CME, de Moraes JAPV, Gimenez CA. (1998). Crescimento, condutância estomática, Fotossíntese e 
Porosidade do buriti sob inundação. Revista Brasileira de Fisiologia Vegetal 10, 51-58.

Rodríguez-Amaya DB. (2001). A guide to Carotenoid Analysis in Foods. ILSI Press, Washinton, 2001. 11-13.

Rojas R. (2000). En: Fundación Peruana para la Conservación de la Naturaleza - ProNaturaleza. (2006). Estudio de las cadenas productivas de aguaje y tagua, Reserva Nacional Pacaya Samiria, Loreto - Perú.

Sall, J, Lehman A, Creighton L. (2001). JMP Start Statistics - A guide to statistics and data analysis using JMP and JMP in software. 2nd ed. USA. 491.

Salisbury FB, Ross CW. (1992). Fisiología Vegetal. Grupo Editorial Iberoamérica. 339-345. USA.

Sayago A, Marín MI, Aparicio R, Morales MT. (2007). Vitamina $\mathrm{E}$ y aceites vegetales. Grasas y Aceites $\mathbf{5 8}$ 74-86.

Trevejo E. (2003). Avances de la investigación en frutos oleaginosos de la Amazonia Peruana. CONCYTECUNAP, 59-83.
Trujillo-Quijano JA, Rodriguez-Amaya DB, Esteves W, Plonis GF. (1990). Carotenoid composition and vitamin A values of oils from four Brazilian palm fruits. Fat Sci. Technol. 92, 222-226.

Ucciani E. (1995). Nouveau Dictionnaire des huiles végétales. Composition en acides gras, Lavoisier.

Urrego LE. (1987). Estudio preliminar de la canangucha (Mauritia flexuosa). Colombia Amazónica 2, 2.

Vásquez-Ocmín PG, Sotero SVE, Del Castillo TD, Freitas AL, Maco LMM. (2009). Diferenciación química de tres morfotipos de Mauritia flexuosa L.f. de la Amazonía Peruana. Revista de la Sociedad Química del Perú 75, $320-328$.

Villachica H. (1996). Frutales y hortalizas promisorios de la Amazonía. Secretaría Pro-Tempore, Tratado de Cooperación Amazónica, pp.367. 